\title{
Mucilage of Coccinia grandis as an Efficient Natural Polymer-Based Pharmaceutical Excipient ${ }^{\dagger}$
}

\author{
Kumbakonam Balachandran Ilango ${ }^{1, * \mathbb{D}}$, Senguttuvan Gowthaman ${ }^{1}$, Kumbakonam Ilango Seramaan ${ }^{2}$ (D), \\ Kumarappan Chidambaram ${ }^{3, * \mathbb{D}}$, Mohammad F. Bayan ${ }^{4}\left(\mathbb{D}\right.$, Mohamed Rahamathulla ${ }^{5}$ (i) and \\ Chandrasekaran Balakumar ${ }^{6}$
}

1 Department of Pharmaceutics, College of Pharmacy, Shree Venkateshwara College of Paramedical Sciences, Erode 638455, India; gowthamanpharma@gmail.com

2 Department of Pharmaceutics, Vellalar College of Pharmacy, Erode 638012, India; seramaan5435@gmail.com

3 Department of Pharmacology, School of Pharmacy, King Khalid University, Abha 62529, Saudi Arabia

4 Faculty of Pharmacy, Philadelphia University, P.O. Box 1, Amman 19392, Jordan; mbayan01@qub.ac.uk

5 Department of Pharmaceutics, School of Pharmacy, King Khalid University, Abha 62529, Saudi Arabia; rahapharm@gmail.com

6 Department of Pharmaceutical Chemistry, School of Pharmacy, ITM University, Gwalior 474001, India; dhillbalu@gmail.com

* Correspondence: kbilango04@gmail.com (K.B.I.); kumarappan@kku.edu.sa (K.C.)

+ Part of this work has been submitted as a thesis by S.G. to The TN Dr MGR Medical University, India.

check for

updates

Citation: Ilango, K.B.; Gowthaman,

S.; Seramaan, K.I.; Chidambaram, K.; Bayan, M.F.; Rahamathulla, M.; Balakumar, C. Mucilage of Coccinia grandis as an Efficient Natural

Polymer-Based Pharmaceutical

Excipient. Polymers 2022, 14, 215.

https://doi.org/10.3390/

polym 14010215

Academic Editor: Anna Maria Piras

Received: 13 December 2021

Accepted: 29 December 2021

Published: 5 January 2022

Publisher's Note: MDPI stays neutral with regard to jurisdictional claims in published maps and institutional affiliations.

Copyright: (C) 2022 by the authors. Licensee MDPI, Basel, Switzerland. This article is an open access article distributed under the terms and conditions of the Creative Commons Attribution (CC BY) license (https:// creativecommons.org/licenses/by/ $4.0 /)$.

\begin{abstract}
Natural eco-friendly materials are recently employed in products to replace synthetic materials due to their superior benefits in preserving the environment. The herb Coccinia grandis is widely distributed in continents like Asia and Africa and used traditionally to treat fever, leprosy, asthma, jaundice, and bronchitis. Mucilage of Coccinia grandis was accordingly extracted, isolated by a maceration technique, and precipitated. The mucilage was evaluated for its physicochemical, binding, and disintegrant properties in tablets using paracetamol as a model drug. The crucial physicochemical properties such as flow properties, solubility, swelling index, loss on drying, viscosity, $\mathrm{pH}$, microbial load, cytotoxicity was evaluated and the compatibility was analyzed using sophisticated instrumental methods (TGA, DTA, DSC, and FTIR). The binding properties of the mucilage was used at three different concentrations and compared with starch and PVP as examples of standard binders. The disintegrant properties of mucilage were used at two different concentrations and compared with standard disintegrants MCCP, SSG, and CCS. The tablets were punched and evaluated for their hardness, friability, assay, disintegration time, in vitro dissolution profiles. In vitro cytotoxicity studies of the mucilage were performed in a human embryonic kidney (HEK) cell line. The outcome of the study indicated that the mucilage had good performance compared with starch and PVP. Further, the mucilage acts as a better disintegrant than MCCP, SSG and CCS for paracetamol tablets. Use of a concentration of $3 \%$ or less demonstrated the ability of the mucilage to act as a super disintegrating agent and showed faster disintegration and dissolution, which makes it as an attractive, promising disintegrant in formulating solid dosage forms to improve the therapeutic efficacy and patient compliance. Moreover, the in vitro cytotoxicity evaluation results demonstrated that the mucilage is non-cytotoxic to human cells and is safe.
\end{abstract}

Keywords: binding agent; disintegrating agent; natural polymer; mucilage; Coccinia grandis

\section{Introduction}

The oral route is the most preferred route of administration of various drugs as it is considered to be the convenient, safe, and painless [1]. Recently, in the novel drug delivery system (NDDS), various researchers developed convenient solid dosage forms and achieved better patient compliance [2]. Various plant gums and mucilages have been used as natural binders and disintegrants in the formulation of tablets [3]. However, 
the identification of an optimized, novel and effective binder and disintegrant for the manufacturing of tablets in the pharmaceutical industry remains a challenging task [4]. Binders and disintegrants are major pharmaceutical excipients that play an important role in solid dosage forms [5]. Binders are employed in tablet formulations to impart cohesion to powder mixtures and hence improve the flow properties of the granules. Thy are used to hold various powders intact together to form a tablet. The wet binder is the most important ingredient in the wet granulation process, and most binders are substances that are hydrophilic and soluble in water such as starch, gelatin, polyvinylpyrrolidone (PVP), etc. [6]. Disintegrating agents are substances routinely incorporated in tablet formulations to assist the breakup of the compacted mass when it is kept into a fluid environment. They also enhance the penetration of moisture and dispersion of the tablet matrix. Notably, the commonly used disintegrating agents in the tablet formulations are microcrystalline cellulose powder (MCCP), croscarmellose sodium (CCS), and sodium starch glycollate (SSG) [7].

Coccinia grandis (L.) Voigt, commonly known as ivy gourd, belongs to the pumpkin (Cucurbitaceae) family. It is frequently found in Asian countries such as India, Pakistan, and Sri Lanka and also distributed in Tropical Africa [8]. Coccinia grandis is a tropical aggressive climbing vine. It is an outdoor plant and can spread vegetatively or by seeds. It is oval with a green to red color. The skin is thick, sticky, and hairless. It becomes sweet, soft, and juicy once it is ripened. In the traditional system of medicine, fruits of Coccinia grandis have been used to treat leprosy, fever, asthma, bronchitis, and jaundice [9-13]. Recently, it was discovered that the polysaccharide found in Coccinia grandis can be used as an anti-diabetic agent [14]. Considering all the above literature reports, the current study was designed to incorporate the isolation of the mucilage from the fruits of Coccinia grandis, evaluation, and its potential applications as a novel binding and disintegrating agent in the tablet formulations.

Paracetamol, also known as acetaminophen or $N$-acetyl-p-aminophenol is widely used over-the-counter analgesic (pain reliever) and antipyretic (fever reducer) was selected in our study as a model drug [15]. Paracetamol is a drug with known capping and lamination problems that normally requires an appropriate binder for its formulation and upon storage, paracetamol tablets gain hardness, thus normally requiring a disintegrant to form ideal tablets. It was found in the literature that the mucilage of this fruit was not studied or reported for its binding and disintegrant properties. Hence, we are interested to investigate for the first time, the binding and disintegrant properties of the mucilage of Coccinia grandis in the tablet formulation and comparing its efficiency with the available standard binding and disintegrating agents.

\section{Materials and Methods}

\subsection{Materials}

Paracetamol (Granules India), Starch (Ridhi Siddhi, Ahmedabad, India), croscarmellose sodium (Shreeji Pharma, Gujarat, India), microcrystalline cellulose powder (Loba Chemie Pvt Ltd., Mumbai, India), sodium starch glycollate (J.R. Pharma, Gujarat, India), polyvinylpyrrolidone (J.B. Khokhani \& Co., Mumbai, India), sodium methylparaben, sodium propylparaben (Nebula Health Care, Gujarat, country), magnesium stearate (Pantogan Chemicals, Chennai, India), talc (Supreme Traders, Coimbatore, India) were received as gift samples from Kreszent Pharma (Pondicherry, India). The fruits of Coccinia grandis were procured from a local market in Coimbatore, India and the same was identified and a specimen was deposited in the Botanical Survey of India, Tamilnadu Agricultural University Campus (Coimbatore, India). All the other chemicals used were of analytical or reagent grade.

\subsection{Extraction and Isolation of Mucilage}

The fruits were thoroughly washed with water. A fruit pulp was made and initially heated with steam at $80^{\circ} \mathrm{C}$ for $3 \mathrm{~min}$ to inhibit enzymatic browning reactions. The fruit 
pulp was homogenized with three times its weight of water. The solution was soaked for $19-20 \mathrm{~h}$ for the release of mucilage into the water. Then the solution was squeezed and filtered using a muslin cloth-bag. The filtrate was collected, and the mucilage was precipitated with three times of its volume of ethanol. Thus, cream-coloured precipitate was obtained and washed with acetone three times $(10 \mathrm{~mL}$ each). The obtained solid was dried initially under vacuum for 17-18 h followed by sunlight exposure for 30 min to yield $5.5 \mathrm{~g}$ mucilage $/ \mathrm{kg}$ of fruits. Finally, the isolated mucilage was powdered, passed through the sieve number 60, and stored inside the desiccator for the future experiments or the subsequent tests.

\subsection{Physicochemical and Characterization of the Isolated Mucilage}

The physicochemical properties such as identification tests, organoleptic properties, solubility, swelling index, loss on drying, viscosity, cytotoxicity, X-ray diffraction (XRD), scanning electron microscopy (SEM), compatibility studies of thermogravimetric analysis (TGA), differential thermal analysis (DTA), differential scanning calorimetry (DSC) and Fourier-transform infrared spectroscopy (FTIR), flow properties, $\mathrm{pH}$ and microbial load of the mucilage were determined according to the corresponding recommended protocols [16-18].

\subsection{Formulations of Paracetamol Granules and Their Key Compositions}

The mucilage was evaluated for its binding and disintegrating properties in tablets of paracetamol (a model drug). Binding properties of granules were evaluated for each of the three different formulations containing varying concentrations $(3 \%, 6 \%$, and $9 \%$ ) of Coccinia grandis mucilage as test binder, starch, and PVP, respectively [19] by a wet granulation technique (Table 1). Disintegrating properties of granules were evaluated for each of the two different formulations containing varying concentrations $(2 \%, 3 \%)$ of mucilage (test disintegrant), and MCCP, CCS, and SSG (standard disintegrants) by a wet granulation technique (Table 2).

Table 1. Composition of paracetamol tablet formulation using the different binding agents of Coccinia Grandis mucilage, Starch and PVP.

\begin{tabular}{|c|c|c|c|c|c|c|c|c|c|}
\hline Ingredients & $\begin{array}{c}\text { F1 } \\
(3 \%)\end{array}$ & $\begin{array}{c}F 2 \\
(6 \%)\end{array}$ & $\begin{array}{c}\text { F3 } \\
(9 \%)\end{array}$ & $\begin{array}{c}F 4 \\
(3 \%)\end{array}$ & $\begin{array}{c}\text { F5 } \\
(6 \%)\end{array}$ & $\begin{array}{c}\text { F6 } \\
(9 \%)\end{array}$ & $\begin{array}{c}\text { F7 } \\
(3 \%)\end{array}$ & $\begin{array}{c}\text { F8 } \\
(6 \%)\end{array}$ & $\begin{array}{l}\text { F9 } \\
(9 \%)\end{array}$ \\
\hline Paracetamol & 250 & 250 & 250 & 250 & 250 & 250 & 250 & 250 & 250 \\
\hline Starch & 125 & 113 & 101 & 125 & 113 & 101 & 125 & 113 & 101 \\
\hline mucilage (Binder) & 12 & 24 & 36 & - & - & - & - & - & - \\
\hline Starch (Binder) & - & - & - & 12 & 24 & 36 & - & - & - \\
\hline $\begin{array}{l}\text { Polyvinylpyrrolidone } \\
\text { (Binder) }\end{array}$ & - & - & - & - & - & - & 12 & 24 & 36 \\
\hline $\begin{array}{c}\text { Sodium } \\
\text { methylparaben }\end{array}$ & 0.8 & 0.8 & 0.8 & 0.8 & 0.8 & 0.8 & 0.8 & 0.8 & 0.8 \\
\hline $\begin{array}{l}\text { Sodium } \\
\text { propylparaben }\end{array}$ & 0.4 & 0.4 & 0.4 & 0.4 & 0.4 & 0.4 & 0.4 & 0.4 & 0.4 \\
\hline $\begin{array}{l}\text { Demineralised } \\
\text { water }\end{array}$ & q.s & q.s & q.s & q.s & q.s & q.s & q.s & q.s & q.s \\
\hline Talc & 8 & 8 & 8 & 8 & 8 & 8 & 8 & 8 & 8 \\
\hline $\begin{array}{l}\text { Magnesium } \\
\text { stearate }\end{array}$ & 4 & 4 & 4 & 4 & 4 & 4 & 4 & 4 & 4 \\
\hline Total weight & 400 & 400 & 400 & 400 & 400 & 400 & 400 & 400 & 400 \\
\hline
\end{tabular}

Note: All the above ingredients quantities are $\mathrm{mg} /$ tablet. 
Table 2. Composition of paracetamol tablet formulation using the different disintegrating agents of Coccinia grandis mucilage, MCCP, CCS, and SSG.

\begin{tabular}{|c|c|c|c|c|c|c|c|c|}
\hline Ingredients & $\begin{array}{c}\text { G1 } \\
(2 \%)\end{array}$ & $\begin{array}{c}\mathrm{G} 2 \\
(3 \%)\end{array}$ & $\begin{array}{c}\text { G3 } \\
(2 \%)\end{array}$ & $\begin{array}{c}\mathrm{G} 4 \\
(3 \%)\end{array}$ & $\begin{array}{c}\text { G5 } \\
(2 \%)\end{array}$ & $\begin{array}{c}\text { G6 } \\
(3 \%)\end{array}$ & $\begin{array}{c}\text { G7 } \\
(2 \%)\end{array}$ & $\begin{array}{c}\text { G8 } \\
(3 \%)\end{array}$ \\
\hline Paracetamol & 250 & 250 & 250 & 250 & 250 & 250 & 250 & 250 \\
\hline Starch (diluent) & 99 & 95 & 99 & 95 & 99 & 95 & 99 & 95 \\
\hline Starch (Binder) & 30 & 30 & 30 & 30 & 30 & 30 & 30 & 30 \\
\hline mucilage & 8 & 12 & - & - & - & - & - & - \\
\hline $\begin{array}{l}\text { Microcrystalline } \\
\text { cellulose powder }\end{array}$ & - & - & 8 & 12 & - & - & - & - \\
\hline $\begin{array}{l}\text { Croscarmellose } \\
\text { sodium }\end{array}$ & - & - & - & - & 8 & 12 & - & - \\
\hline $\begin{array}{l}\text { Sodium starch } \\
\text { glycollate }\end{array}$ & - & - & - & - & - & - & 8 & 12 \\
\hline $\begin{array}{c}\text { Sodium } \\
\text { methylparaben }\end{array}$ & 0.8 & 0.8 & 0.8 & 0.8 & 0.8 & 0.8 & 0.8 & 0.8 \\
\hline $\begin{array}{l}\text { Sodium } \\
\text { propylparaben }\end{array}$ & 0.4 & 0.4 & 0.4 & 0.4 & 0.4 & 0.4 & 0.4 & 0.4 \\
\hline Demineralised water & q.s & q.s & q.s & q.s & q.s & q.s & q.s & q.s \\
\hline Talc & 8 & 8 & 8 & 8 & 8 & 8 & 8 & 8 \\
\hline Magnesium stearate & 4 & 4 & 4 & 4 & 4 & 4 & 4 & 4 \\
\hline Total weight & 400 & 400 & 400 & 400 & 400 & 400 & 400 & 400 \\
\hline
\end{tabular}

Note: All the above ingredients quantities are $\mathrm{mg} /$ tablet.

\subsection{Evaluation of Granules}

The flow properties of the granules were determined for their bulk density, tapped density, (compressibility index), Carr's index, Hausner's ratio, and angle of repose as per the reported protocols [20].

\subsection{Production and Evaluation of Tablets Formulations}

The different batches of granules were formulated and compressed into an average weight of $400 \mathrm{mg}$ per tablet using a rotary tablet compression machine (Shakti Pharmatech Pvt Ltd., Chennai, India) fitted with a concave punch and die set. The prepared tablets were evaluated for their hardness, friability, weight variation, assay, disintegration time, in vitro dissolution profiles, and accelerated stability studies using the suitable methods specified in the Indian Pharmacopoeia (IP) 2007 [21].

\section{Results and Discussion}

\subsection{Physicochemical Characterization of Isolated Mucilage Powder}

The physicochemical and microbiological properties of the mucilage were determined and the results are collected in Tables 3 and 4. The reports of the identification tests of mucilage indicated the presence of carbohydrate, mucilage and polysaccharides through the Molisch's, ruthenium and iodine tests, respectively. The extracted and purified mucilage was evaluated for its viscosity, bacterial load, and $\mathrm{pH}$. The microbial count of bacteria and fungi was found to be less than 300 and $100 \mathrm{CFU}$ (colony forming units) per gram of mucilage, respectively. The $\mathrm{pH}$ of the mucilage was found to be 6.7. Since the $\mathrm{pH}$ value of this mucilage is near to neutral, it may be less irritating on the gastrointestinal tract (GIT) and hence, it will be suitable for the uncoated tablets formulations. The flow-properties of the mucilage powders were determined by Carr's index, Hausner's ratio and angle of repose and were found to be $>23,>1.25$, and $36^{\circ}-40^{\circ}$, respectively, all of which indicated acceptable flow properties. 
Table 3. Identification test results of the mucilage.

\begin{tabular}{ccc}
\hline Tests & Observed & Results \\
\hline Molisch's test: & Violet green colour present at & Carbohydrate present \\
Ruthenium test: & junction of two layers & Mucilage present \\
Iodine test: & Pink colour developed & Polysaccharides present \\
\hline
\end{tabular}

Table 4. Results of Physicochemical characterization of Coccinia grandis mucilage.

\begin{tabular}{cc}
\hline Parameters & Observed \\
\hline Organoleptic properties & $\begin{array}{c}\text { White colour, amorphous nature, tasteless, } \\
\text { characteristic odour. }\end{array}$ \\
Solubility & $\begin{array}{c}\text { Slightly soluble in hot water, in cold water forming } \\
\text { viscous colloidal solution and practically insoluble in }\end{array}$ \\
acetone, ethanol, chloroform and other organic \\
solvents.
\end{tabular}

\subsection{Thermal Methods of Analysis}

The drug-excipient compatibility studies were analyzed using thermal methods of analysis such as TGA, DTA, and DSC. The results of thermal analyses of mucilage of C. grandis demonstrated that there is no change in melting point which confirmed that there is neither changes in the colour of the drug nor had any interaction.

\subsection{Thermogravimetric Analysis (TGA)}

The thermogravimetric curve of the Coccinia grandis mucilage (CGM) is presented in Figure 1. It clearly shows the weight loss corresponding to the loss of water around $25-190{ }^{\circ} \mathrm{C}$. The mucilage underwent $9.26 \%$ weight loss at $65.21^{\circ} \mathrm{C}$ which implied that CGM had good thermal stability. The curve also indicated that the mucilage did not decompose before $200{ }^{\circ} \mathrm{C}$ and starts to decompose at $207.34{ }^{\circ} \mathrm{C}$. Hence, water is formed by intraand inter-molecular condensation of the mucilage hydroxyls are the main products of decomposition at a temperature below $450{ }^{\circ} \mathrm{C}$. The TGA of CGM and drug mixture showed no major interaction of CGM and drug (Figure 2), hence the mixtures are compatible with each other. 


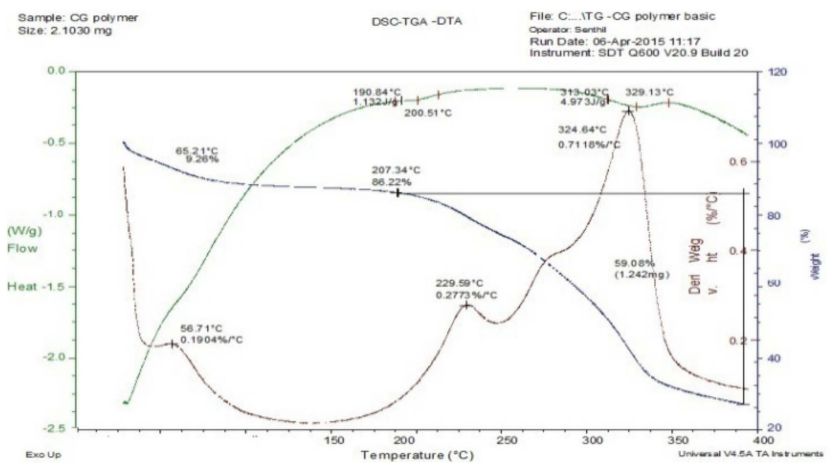

Figure 1. DSC, TGA, DTA of mucilage (CGM).

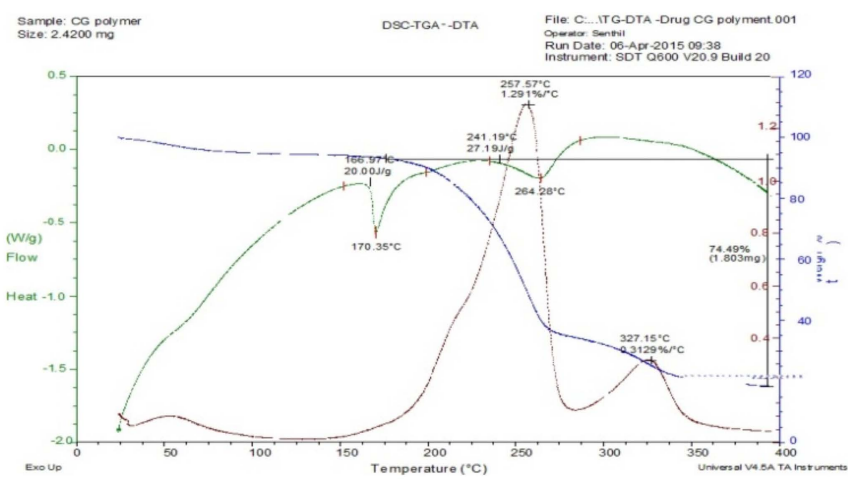

Figure 2. DSC, TGA, DTA of paracetamol + CGM.

\subsection{Differential Scanning Colorimetry (DSC)}

The DSC curve of CGM (Figure 1) demonstrated that it undergoes a glass transition at a temperature to $190.84{ }^{\circ} \mathrm{C}(1.132 \mathrm{~J} / \mathrm{G})$. The continuous (broad) endothermic transition that recedes the glass transition is an indicative of moisture loss in the sample and start decomposing at $313.03{ }^{\circ} \mathrm{C}(4.973 \mathrm{~J} / \mathrm{G})$. The sample DSC overlap curve of CGM, drug, and its mixture (Figure 2) showed no additional peaks. Hence, it can be concluded that there is no physical interaction occurred in the mixture of CGM with the drug paracetamol.

\subsection{Differential Thermal Analysis (DTA)}

The DTA curve of mucilage undergoes crystallization at a temperature of $56.71{ }^{\circ} \mathrm{C}$ $\left(0.1904 \% /{ }^{\circ} \mathrm{C}\right)$. The mucilage started to melt at $229.59{ }^{\circ} \mathrm{C}\left(0.2773 \% /{ }^{\circ} \mathrm{C}\right)$ based on the analysis conducted using DTA as shown in Figure 1. The DTA of the mixture of paracetamol drug and mucilage displayed no major interaction between CGM and drug (Figure 2). Hence, the mucilage and drug were compatible with each other. Figure 3 presents DSC, TGA, DTA of the model drug paracetamol alone.

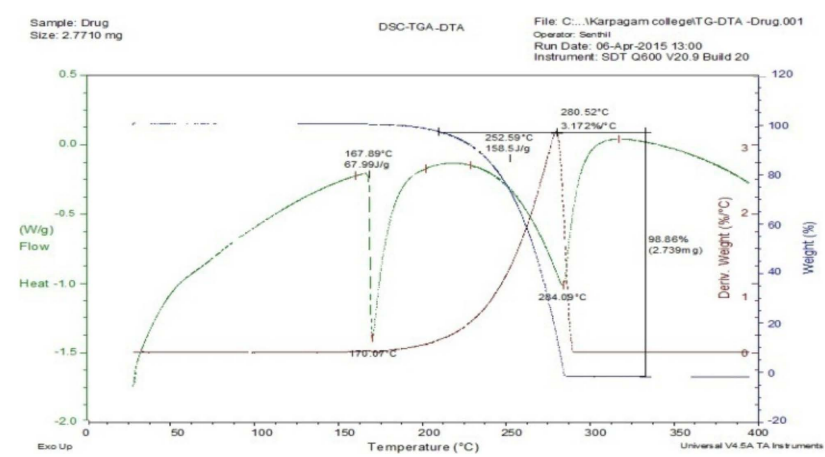

Figure 3. DSC, TGA, DTA of Paracetamol. 


\subsection{FTIR Analysis}

The drug-excipient interaction was also verified by comparing the FTIR spectrum of the physical mixture of the drug with the mucilage of $C$. grandis with FTIR spectrum of the pure drug paracetamol. The main components of the mucilage (CGM) may be galactose, rhamnose, and galacturonic acid as shown in the FTIR spectrum (Figure 4). A broad stretching peak observed at $3385.07 \mathrm{~cm}^{-1}$ indicated the presence of the $\mathrm{O}-\mathrm{H}$ functional group as the main functional group of carbohydrates/polysaccharides as the three main components of CGM. The O-H groups can bind with water molecules and produce bound moisture to the mucilage components. The existence of $\mathrm{O}-\mathrm{H}$ groups represents the hydrophilicity of the mucilage. Besides, $\mathrm{O}-\mathrm{H}$ group, the carbonyl $(\mathrm{C}=\mathrm{O})$ stretching peak observed at $1629.85 \mathrm{~cm}^{-1}$ in the FTIR confirmed the chemical nature of CGM containing mostly carbohydrate molecules, which is considered to be the main backbone of the mucilage. The FTIR spectrum of paracetamol is presented in the Figure 5. The FTIR spectrum of the mixture of mucilage and drug is shown in Figure 6 that disclosed distinctive stretching vibrational peaks at $3317.56 \mathrm{~cm}^{-1}, 3165.19 \mathrm{~cm}^{-1}, 1654.92 \mathrm{~cm}^{-1}$, and $1560.41 \mathrm{~cm}^{-1}$ corresponding to the functional groups present in the mucilage and the drug. Further, there are no abnormal peaks, and the functional groups of the drug are seen intact which in turn demonstrated that the drug is compatible with mucilage.

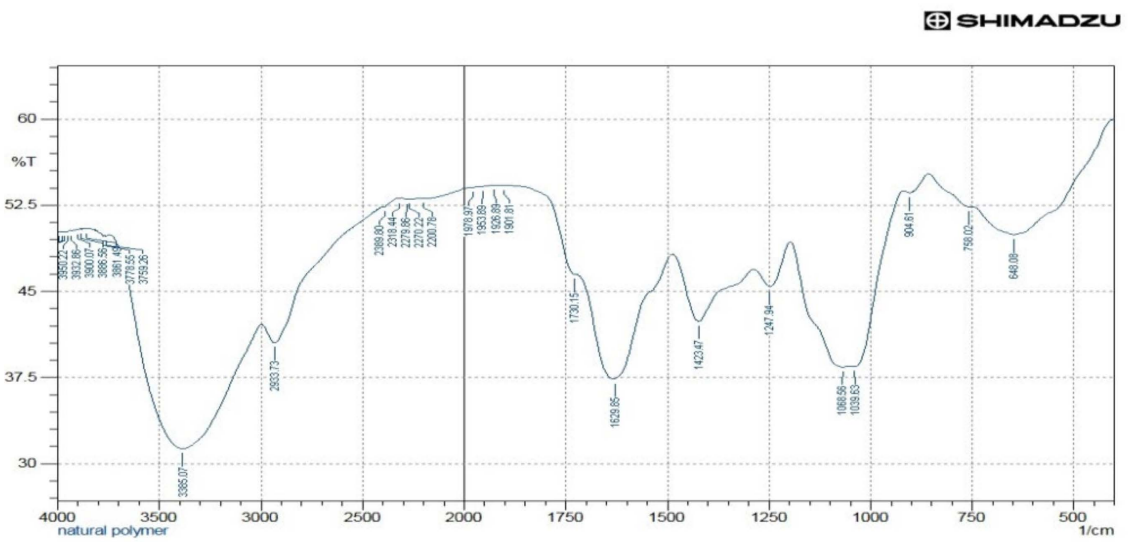

Figure 4. FTIR analysis of the mucilage.

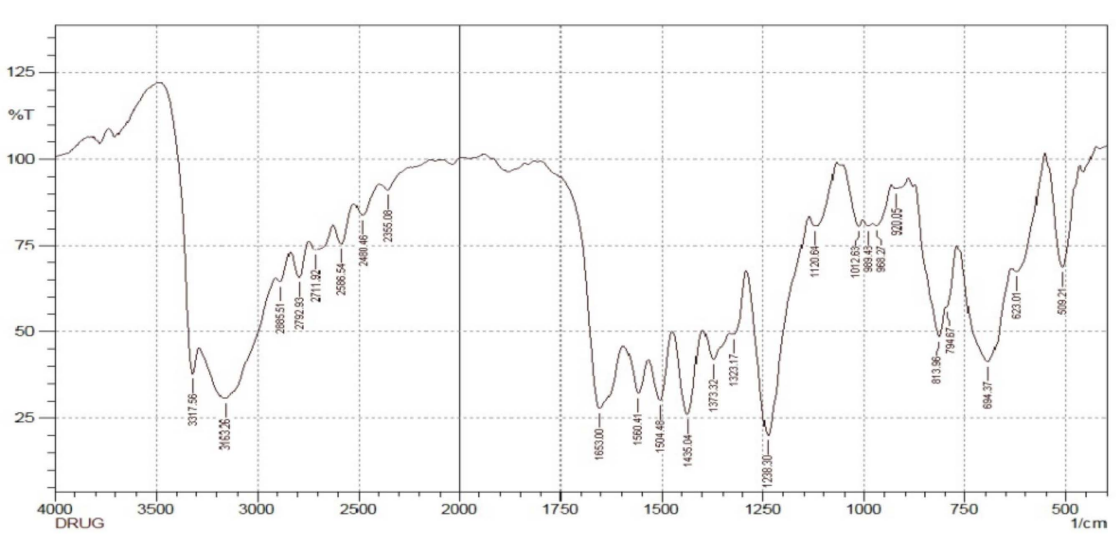

Figure 5. FTIR analysis of paracetamol.

The vibrational frequencies of various functional groups of the pure drug remained intact in the physical mixture containing C. grandis according to the Figure 6 . Thus, it was concluded that there was no major interaction occurred between the drug and C. grandis used in the current study. Hence, the mucilage can be used effectively as a pharmaceutical excipient in the tablet formulations. 
Ф SHIMADZU

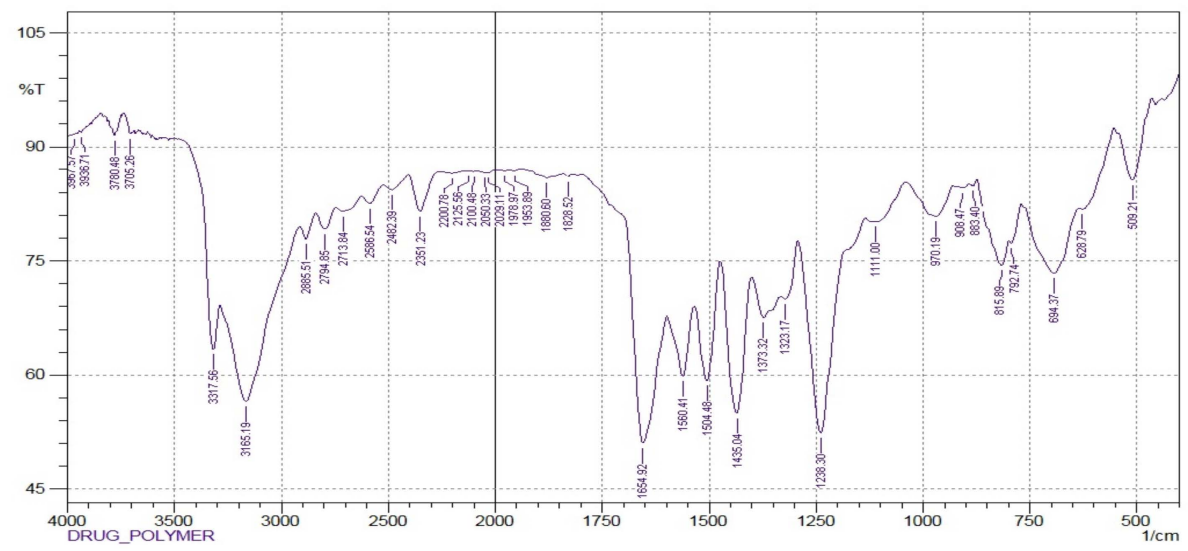

Figure 6. FTIR analysis of the mucilage $(\mathrm{CGM})+$ paracetamol.

\subsection{X-ray Powder Diffraction Study}

The surface morphology of the mucilage powder was observed by the X-ray diffraction (XRD) method and the results are shown in the Figure 7. From the spectra obtained through $\mathrm{XRD}$, it was deduced that the mucilage powder showed the presence of numerous halos with weak peaks which in turn confirmed the amorphous nature of the material.

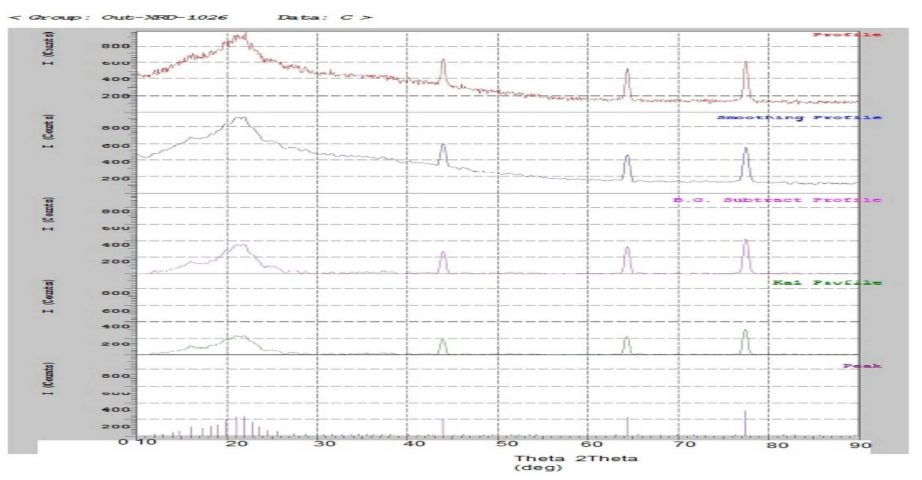

Figure 7. XRD analysis of mucilage (CGM).

\subsection{Scanning Electron Microscopy}

The surface morphology of the mucilage was also observed under scanning electron microscope (SEM) analysis and the result at $\times 5000$ is shown in Figure 8 . Further, the images of SEM results under different magnification are presented in Supplementary Materials (Figures S1-S3). The images of the mucilage revealed that the surface of particles is mostly seen as aggregates of rough, irregular in size and shapes and dimensions which were fibrous in nature, subsequently confirmed the amorphous nature of the material. 


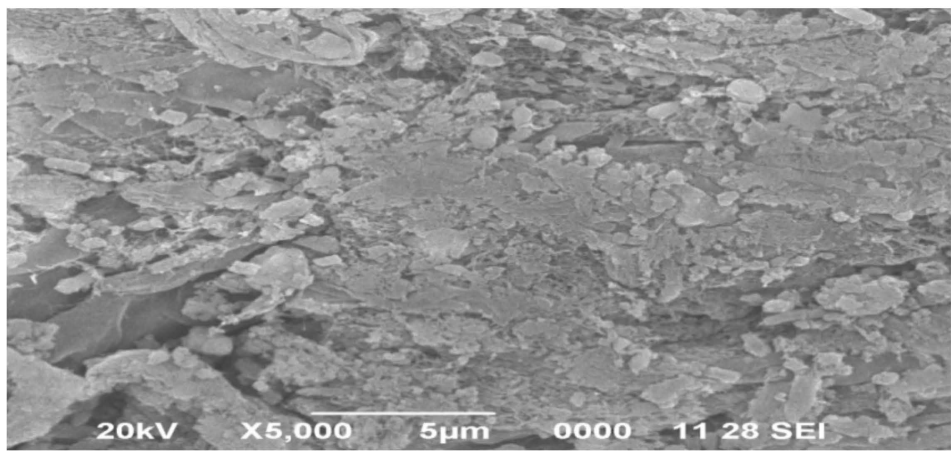

Figure 8. SEM analysis of mucilage in $\times 5000$.

\subsection{In Vitro Cytotoxicity Evaluation}

The toxicity study of the mucilage was performed in the human embryonic kidney (HEK) cell line. The cells were maintained at $37{ }^{\circ} \mathrm{C}, 5 \% \mathrm{CO}_{2}, 95 \%$ air, and $100 \%$ relative humidity. The concentration Vs absorbance and percentages of cell viability of test sample were calculated with control sample and are collected in Tables 5 and 6 and the images are presented in the Supplementary Materials (Figures S4-S10). The HEK cell line had no morphological changes, and the cell viability was nearly $100 \%$ (i.e., above $80 \%$ ). The reduction of MTT by cells indicated the mitochondrial activity, which may be interpreted as a proof of cell viability. It was concluded that the CGM unable to induce cytotoxic effects to the normal cells at the used concentrations.

Table 5. Concentration vs. absorbance of cell viability of test and control.

\begin{tabular}{ccc}
\hline S. No & Concentration $(\mu \mathrm{g} / \mathrm{mL})$ & Absorbance \\
\hline 1 & 12.5 & 0.451 \\
2 & 25 & 0.446 \\
3 & 50 & 0.413 \\
4 & 100 & 0.388 \\
5 & 200 & 0.367 \\
\hline
\end{tabular}

Average control absorbance $=0.451$.

Table 6. Concentrations vs. \% cell viability.

\begin{tabular}{ccc}
\hline S. No & Concentration $(\mu \mathrm{g} / \mathrm{mL})$ & \% Cell Viability \\
\hline 1 & 12.5 & 99.92 \\
2 & 25 & 98.81 \\
3 & 50 & 91.65 \\
4 & 100 & 85.96 \\
5 & 200 & 81.38 \\
\hline
\end{tabular}

\subsection{Evaluation of the Formulated Granules for Flow Properties}

The flow properties of the prepared granules of different batches were determined and the results are shown in Tables 7 and 8. A decrease in flowability was observed when the concentration (as a binding agent) of the mucilage is increased. While compared with standard starch and PVP granules, the flow property of the formulated granules differs slightly. If the concentration of the mucilage is increased as a as a disintegrating agent, then the flowability is also increased, correspondingly. This value slightly deviates from the flow properties of the granules prepared from standard excipients (MCCP, CCS, and SSG). The Carr's index, Hausner's ratio and angle of repose values of the granules prepared using the mucilage were found to be $<23,<1.25$, and $25^{\circ}-30^{\circ}$, respectively. Hence, it was concluded that all the granules exhibited excellent flow properties. 
Table 7. Flow properties of formulated granules (Binding agents).

\begin{tabular}{|c|c|c|c|c|c|c|c|c|c|}
\hline \multirow{3}{*}{$\begin{array}{c}\text { Binders } \\
\text { Formulations Code } \\
\text { Parameters }\end{array}$} & \multicolumn{3}{|c|}{ CGM } & \multicolumn{3}{|c|}{ STARCH } & \multicolumn{3}{|c|}{ PVP } \\
\hline & \multirow{2}{*}{ F1 (3\%) } & \multirow{2}{*}{ F2 (6\%) } & \multirow{2}{*}{ F3 (9\%) } & \multirow{2}{*}{ F4 (3\%) } & \multirow{2}{*}{ F5 $(6 \%)$} & \multirow{2}{*}{ F6 (9\%) } & \multirow{2}{*}{ F7 (3\%) } & \multirow{2}{*}{ F8 $(6 \%)$} & \multirow{2}{*}{ F9 $(9 \%)$} \\
\hline & & & & & & & & & \\
\hline Bulk density ( $\mathrm{g} / \mathrm{mL})$ & 0.438 & 0.446 & 0.446 & 0.434 & 0.442 & 0.446 & 0.438 & 0.446 & 0.442 \\
\hline DüK aensity (g/mL) & \pm 0.00 & \pm 0.00 & \pm 0.00 & \pm 0.00 & \pm 0.00 & \pm 0.00 & \pm 0.00 & \pm 0.00 & \pm 0.00 \\
\hline Tapped density & 0.510 & 0.500 & 0.495 & 0.526 & 0.500 & 0.490 & 0.505 & 0.490 & 0.480 \\
\hline$(\mathrm{g} / \mathrm{mL})$ & \pm 0.00 & \pm 0.00 & \pm 0.00 & \pm 0.00 & \pm 0.00 & \pm 0.00 & \pm 0.00 & \pm 0.00 & \pm 0.00 \\
\hline & 14.1 & 10.8 & 9.9 & 17.5 & 11.6 & 9.0 & 13.3 & 9.0 & 7.9 \\
\hline Carr's index (\%) & \pm 0.00 & \pm 0.00 & \pm 0.01 & \pm 0.01 & \pm 0.00 & \pm 0.03 & \pm 0.04 & \pm 0.03 & \pm 0.00 \\
\hline & 1.16 & 1.12 & 1.11 & 1.21 & 1.13 & 1.10 & 1.15 & 1.10 & 1.10 \\
\hline Hausner's ratio & \pm 0.00 & \pm 0.00 & \pm 0.01 & \pm 0.00 & \pm 0.00 & \pm 0.01 & \pm 0.00 & \pm 0.01 & \pm 0.02 \\
\hline Angle of repose $\left(^{\circ}\right)$ & $29.3^{\circ}$ & $25.1^{\circ}$ & $26.2^{\circ}$ & $29.7^{\circ}$ & $26.4^{\circ}$ & $25.9^{\circ}$ & $29.9^{\circ}$ & $28.4^{\circ}$ & $27.8^{\circ}$ \\
\hline
\end{tabular}

CGM = mucilage, $\mathrm{PVP}=$ polyvinylpyrrolidone.

Table 8. Flow properties of formulated granules (Disintegrating agents).

\begin{tabular}{|c|c|c|c|c|c|c|c|c|}
\hline \multirow{3}{*}{$\begin{array}{c}\text { Disintegrants } \\
\text { Formulations Code } \\
\text { Parameters } \\
\end{array}$} & \multicolumn{2}{|c|}{ CGM } & \multicolumn{2}{|c|}{ МССР } & \multicolumn{2}{|c|}{$\mathrm{CCS}$} & \multicolumn{2}{|c|}{ SSG } \\
\hline & \multirow{2}{*}{ G1 (2\%) } & \multirow{2}{*}{ G2 (3\%) } & \multirow{2}{*}{ G3 $(2 \%)$} & \multirow{2}{*}{ G4 (3\%) } & \multirow{2}{*}{ G5 (2\%) } & \multirow{2}{*}{ G6 (3\%) } & \multirow{2}{*}{ G7 (2\%) } & \multirow{2}{*}{ G8 (3\%) } \\
\hline & & & & & & & & \\
\hline Bulk density (g/mL) & $\begin{array}{c}0.446 \\
\pm 0.00\end{array}$ & $\begin{array}{c}0.442 \\
\pm 0.00\end{array}$ & $\begin{array}{c}0.446 \\
\pm 0.00\end{array}$ & $\begin{array}{c}0.442 \\
\pm 0.00\end{array}$ & $\begin{array}{c}0.442 \\
\pm 0.00\end{array}$ & $\begin{array}{c}0.446 \\
\pm 0.00\end{array}$ & $\begin{array}{c}0.442 \\
\pm 0.00\end{array}$ & $\begin{array}{c}0.446 \\
\pm 0.00\end{array}$ \\
\hline $\begin{array}{l}\text { Tapped density } \\
\qquad(\mathrm{g} / \mathrm{mL})\end{array}$ & $\begin{array}{l}0.495 \\
\pm 0.00\end{array}$ & $\begin{array}{l}0.500 \\
\pm 0.00\end{array}$ & $\begin{array}{l}0.500 \\
\pm 0.00\end{array}$ & $\begin{array}{l}0.505 \\
\pm 0.00\end{array}$ & $\begin{array}{l}0.500 \\
\pm 0.00\end{array}$ & $\begin{array}{l}0.495 \\
\pm 0.00\end{array}$ & $\begin{array}{l}0.505 \\
\pm 0.00\end{array}$ & $\begin{array}{l}0.490 \\
\pm 0.00\end{array}$ \\
\hline Carr's index (\%) & $\begin{array}{l}9.9 \\
\pm 0.01\end{array}$ & $\begin{array}{l}11.6 \\
\pm 0.00\end{array}$ & $\begin{array}{c}10.8 \\
\pm 0.01\end{array}$ & $\begin{array}{c}12.5 \\
\pm 0.03\end{array}$ & $\begin{array}{c}11.6 \\
\pm 0.00\end{array}$ & $\begin{array}{c}9.9 \\
\pm 0.01\end{array}$ & $\begin{array}{c}12.5 \\
\pm 0.03\end{array}$ & $\begin{aligned} & 9.0 \\
\pm & 0.03\end{aligned}$ \\
\hline Hausner's ratio & $\begin{array}{c}1.11 \\
\pm 0.01\end{array}$ & $\begin{array}{l}1.13 \\
\pm 0.01\end{array}$ & $\begin{array}{l}1.12 \\
\pm 0.01\end{array}$ & $\begin{array}{c}1.14 \\
\pm 0.00\end{array}$ & $\begin{array}{l}1.13 \\
\pm 0.01\end{array}$ & $\begin{array}{c}1.11 \\
\pm 0.01\end{array}$ & $\begin{array}{c}1.14 \\
\pm 0.00\end{array}$ & $\begin{array}{l}1.10 \\
\pm 0.01\end{array}$ \\
\hline Angle of repose $\left(^{\circ}\right)$ & $28.3^{\circ}$ & $29.1^{\circ}$ & $28.7^{\circ}$ & $29.7^{\circ}$ & $28.4^{\circ}$ & $28.9^{\circ}$ & $29.2^{\circ}$ & $28.8^{\circ}$ \\
\hline
\end{tabular}

$\mathrm{CGM}=$ mucilage, $\mathrm{MCCP}=$ microcrystalline cellulose powder, $\mathrm{CCS}=$ croscarmellose sodium, $\mathrm{SSG}=$ sodium starch glycollate.

\subsection{Evaluation of Tablets Using Isolated Mucilage as a Binding Agent}

By employing the isolated mucilage as a binding agent at three different percentages, a few batches of tablets were manufactured. For comparison purposes, starch and PVP were used as standard binding agents in the evaluation. The formulated tablets were evaluated and the results of various parameters such as weight variation, hardness, thickness, diameter, friability, disintegration time, and assay were shown in the Table 9. All the prepared batches of tablets exhibited a good content uniformity. The hardness of the tablets proportionally increasing with an increase in the percentage of used binding agents. Tablets prepared with $9 \%$ mucilage showed more hardness when compared to the tablets prepared using $3 \%$ or $6 \%$. The friability test values were found to be lower with an increase in the concentration of the binder, however, the overall friability falls within the specified IP limits. The disintegration time of the tablets increases as increase in the concentration of the binder from $3 \%$ to $9 \%$. This behaviour can be attributed to the swelling properties of the mucilage. But the overall disintegration time values were within the IP prescribed limits.

Table 9. Evaluation of tablets using different binding agents.

\begin{tabular}{|c|c|c|c|c|c|c|c|c|c|}
\hline Binders & \multirow{3}{*}{ F1 (3\%) } & \multicolumn{2}{|l|}{ CGM } & \multicolumn{3}{|c|}{ STARCH } & \multicolumn{3}{|c|}{ PVP } \\
\hline Formulations Code & & & & & & & & & \\
\hline Parameters & & $F 2(6 \%)$ & F3 $(9 \%)$ & $F 4(3 \%)$ & F5 (6\%) & $F 6(9 \%)$ & F7 (3\%) & $F 8(6 \%)$ & F9 (9\%) \\
\hline Weight variation (mg) & 400.1 & 400.0 & 401.4 & 400.0 & 401.1 & 400.2 & 401.0 & 401.2 & 400.1 \\
\hline Hardness $\left(\mathrm{kg} / \mathrm{cm}^{2}\right)$ & 4.0 & 4.5 & 5.5 & 4.0 & 4.5 & 5.0 & 4.5 & 5.0 & 6.5 \\
\hline Thickness (mm) & 4.8 & 4.8 & 5.0 & 4.8 & 5.0 & 4.8 & 4.9 & 5.0 & 4.8 \\
\hline Diameter (mm) & 10.14 & 10.14 & 10.12 & 10.14 & 10.12 & 10.14 & 10.14 & 10.14 & 10.14 \\
\hline Friability $(\% w / w)$ & 0.97 & 0.68 & 0.49 & 0.85 & 0.61 & 0.47 & 0.77 & 0.52 & 0.41 \\
\hline $\begin{array}{l}\text { Disintegration time } \\
\text { (min) }\end{array}$ & $2 \mathrm{~min} / 5 \mathrm{~s}$ & $4 \mathrm{~min} / 2 \mathrm{~s}$ & $6 \mathrm{~min} / 28 \mathrm{~s}$ & $1 \mathrm{~min} / 48 \mathrm{~s}$ & $3 \mathrm{~min} / 52 \mathrm{~s}$ & $5 \mathrm{~min} / 22 \mathrm{~s}$ & $1 \mathrm{~min} / 54 \mathrm{~s}$ & $5 \mathrm{~min} / 49 \mathrm{~s}$ & $13 \mathrm{~min} / 36 \mathrm{~s}$ \\
\hline Assay (\%) & 99.7 & 99.6 & 98.9 & 100.1 & 98.8 & 99.8 & 98.7 & 100.2 & 99.9 \\
\hline
\end{tabular}




\subsection{Evaluation of Tablets Using Isolated Mucilage as a Disintegrating Agent}

Different batches of tablets were prepared using isolated mucilage as a suitable disintegrating agent at two different concentrations. For comparison, MCCP, CCS, and SSG were employed as standard disintegrating agents. The prepared tablets were evaluated and the results of their weight variation, hardness, thickness, diameter, friability, disintegration time, and assay are presented in Table 10. All the batches of tablets exhibited a good content uniformity, and a hardness between 4.0 to $4.5 \mathrm{~kg} / \mathrm{cm}^{2}$ was observed. The friability of the tablets was found to be within the approved range of less than 0.5 to $1 \%$ as per IP. The disintegration time of the isolated mucilage was determined to be within 15 min as per IP limits which indicated a slight difference or almost equal to the standard disintegrants. The disintegration time of tablets was found to be decreased with an increase in the concentration of the used mucilage. When the mucilage concentration was increased above $3 \%$, the disintegration time also increased, accordingly. Thus, the mucilage acts as a suitable disintegrating agent, at an ideal concentration of less than $3 \%$.

Table 10. Evaluation of tablets using different disintegrating agents.

\begin{tabular}{|c|c|c|c|c|c|c|c|c|}
\hline \multirow{2}{*}{$\begin{array}{c}\text { Disintegrants } \\
\text { Formulations Code }\end{array}$} & \multicolumn{2}{|c|}{ CGM } & \multicolumn{2}{|c|}{ MCCP } & \multicolumn{2}{|c|}{ CCS } & \multicolumn{2}{|c|}{ SSG } \\
\hline & \multirow{2}{*}{ G1 (2\%) } & \multirow{2}{*}{ G2 (3\%) } & \multirow{2}{*}{ G3 (2\%) } & \multirow{2}{*}{ G4 (3\%) } & \multirow{2}{*}{ G5 (2\%) } & \multirow{2}{*}{ G6 (3\%) } & \multirow{2}{*}{ G7 (2\%) } & \multirow{2}{*}{ G8 (3\%) } \\
\hline Parameters & & & & & & & & \\
\hline $\begin{array}{l}\text { Weight variation } \\
\text { (mg) }\end{array}$ & 400.0 & 400.3 & 400.1 & 401.0 & 400.1 & 399.9 & 401.2 & 400.7 \\
\hline Hardness $\left(\mathrm{kg} / \mathrm{cm}^{2}\right)$ & 4.0 & 4.0 & 4.0 & 4.5 & 4.0 & 4.0 & 4.5 & 4.0 \\
\hline Thickness (mm) & 4.8 & 4.8 & 4.8 & 4.9 & 4.8 & 4.8 & 5.0 & 4.9 \\
\hline Diameter (mm) & 10.14 & 10.14 & 10.14 & 10.12 & 10.14 & 10.14 & 10.14 & 10.14 \\
\hline Friability $(\% w / w)$ & 0.44 & 0.42 & 0.45 & 0.42 & 0.48 & 0.43 & 0.44 & 0.47 \\
\hline $\begin{array}{l}\text { Disintegration time } \\
\text { (min) }\end{array}$ & $2 \mathrm{~min} / 58 \mathrm{~s}$ & $2 \mathrm{~min} / 22 \mathrm{~s}$ & $2 \mathrm{~min} / 51 \mathrm{~s}$ & $2 \mathrm{~min} / 36 \mathrm{~s}$ & $2 \mathrm{~min} / 49 \mathrm{~s}$ & $2 \mathrm{~min} / 12 \mathrm{~s}$ & $2 \mathrm{~min} / 51 \mathrm{~s}$ & $2 \mathrm{~min} / 17 \mathrm{~s}$ \\
\hline Assay (\%) & 98.9 & 99.9 & 99.7 & 100.1 & 99.8 & 98.9 & 99.6 & 98.7 \\
\hline
\end{tabular}

\subsection{In Vitro Dissolution Studies of Tablets Using Isolated Mucilage as a Binding Agent}

In vitro dissolution profile of tablets is shown in Figures 9 and 10, Tables 11 and 12. The results of this study showed that the drug release from the tablets prepared using the mucilage with $3 \%$ and $6 \%$ concentrations were found to be more than $80 \%$, whereas using $9 \%$ concentration of the mucilage, the drug release of $80 \%$ occurred in $30 \mathrm{~min}$. The drug release was found to be increased with a decrease in the concentration of the mucilage. From the Figure 10, the drug release of F1 and F2 batches showed a sharp increase, whereas F3 showed minimal drug release while comparing with other standard batches. The friability and disintegration time of all the formulations were identified to be within the IP standards. The drug release of F1 and F2 formulations is within IP standard, except the formulation F3.

Table 11. Statistical factors of CGM compared with STARCH and PVP as binding agents.

\begin{tabular}{|c|c|c|c|c|c|c|}
\hline \multirow{2}{*}{$\begin{array}{c}\text { Binders } \\
\text { Formulations Code }\end{array}$} & \multicolumn{3}{|c|}{ CGM vs. STARCH } & \multicolumn{3}{|c|}{ CGM vs. PVP } \\
\hline & \multirow{2}{*}{ F1 vs. F4 (3\%) } & \multirow{2}{*}{ F2 vs. F5 (6\%) } & \multirow{2}{*}{ F3 vs. F6 $(9 \%)$} & \multirow{2}{*}{ F1 vs. F7 (3\%) } & \multirow{2}{*}{ F2 vs. F8 (6\%) } & \multirow{2}{*}{ F3 vs. F9 $(9 \%)$} \\
\hline Statistical Factors & & & & & & \\
\hline Difference factor (f1) & 2.01 & 3.90 & 4.93 & 3.91 & 13.99 & 9.98 \\
\hline Similarity factor (f2) & 87.48 & 80.91 & 78.15 & 76.69 & 54.37 & 63.82 \\
\hline 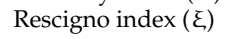 & 0.0113 & 0.0207 & 0.0252 & 0.0209 & 0.0606 & 0.0468 \\
\hline
\end{tabular}


Table 12. Statistical factors of CGM compared with MCCP, CCS and SSG as disintegrating agents.

\begin{tabular}{|c|c|c|c|c|c|c|}
\hline \multirow{2}{*}{$\begin{array}{c}\text { Disintegrants } \\
\text { Formulations Code }\end{array}$} & \multicolumn{2}{|c|}{ CGM vs. MCCP } & \multicolumn{2}{|c|}{ CGM vs. CCS } & \multicolumn{2}{|c|}{ CGM vs. SSG } \\
\hline & & & & & & \\
\hline Statistical Factors & G1 vs. G3 $(2 \%)$ & G2 vs. G4 (3\%) & G1 vs. G5 ( $2 \%)$ & G2 vs. G6 (3\%) & G1 vs. G7 ( $2 \%)$ & G2 vs. G8 (3\%) \\
\hline $\begin{array}{l}\text { Difference factor } \\
\text { (f1) }\end{array}$ & 2.00 & 1.49 & 1.99 & 1.94 & 1.03 & 0.99 \\
\hline Similarity factor (f2) & 87.71 & 89.75 & 87.51 & 87.51 & 92.04 & 92.04 \\
\hline Rescigno index $(\xi)$ & 0.0099 & 0.0070 & 0.0114 & 0.0098 & 0.0059 & 0.0057 \\
\hline
\end{tabular}

3.14. In Vitro Dissolution Studies of Tablets Using Isolated Mucilage as a Disintegrating Agent

In vitro dissolution profiles of tablets are shown in Figures 9-11 and the parameters are presented in the Supplementary Materials as Tables S1-S3. The drug release from the tablets prepared using the mucilage with $2 \%$ and $3 \%$ concentrations were found to be more than $80 \%$ in $30 \mathrm{~min}$ (as per IP limits). The drug release was found to be increased with an increase in the concentration of mucilage (as a disintegrant). The formulation of G1 (2\%) and G2 (3\%) showed good disintegrant and the drug release was accomplished as above $80 \%$ (within the limit as per IP). Above 3\% of the mucilage concentration, the disintegration time was slightly increased and conversely, the dissolution time decreased. Hence, the mucilage acts as an appropriate disintegrating agent within the concentration range of 1 to $3 \%$.

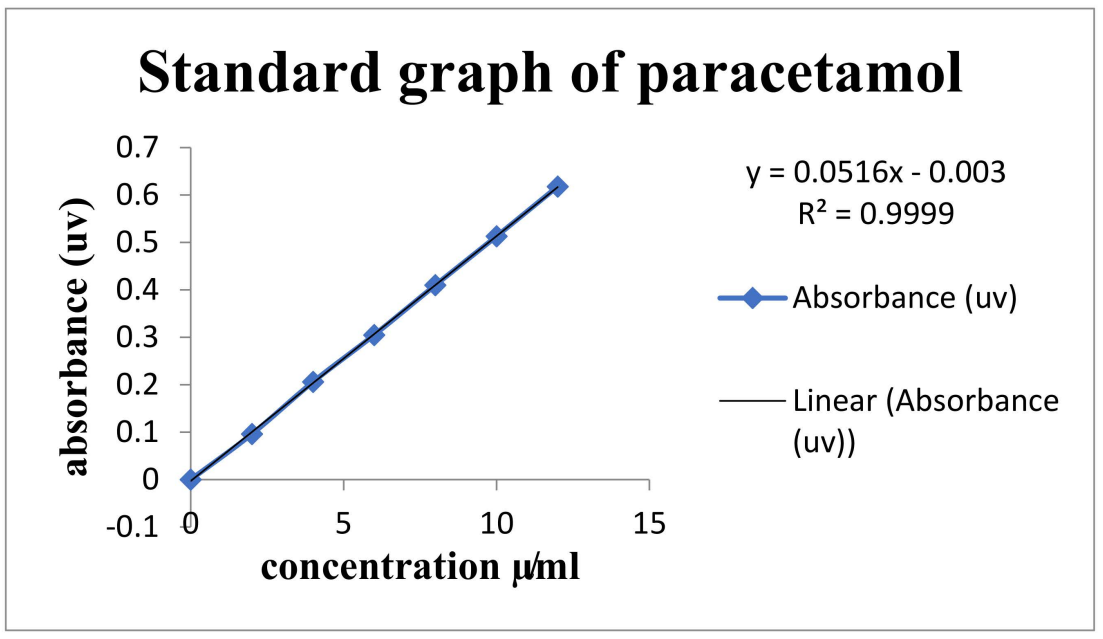

Figure 9. Standard graph of paracetamol drug.

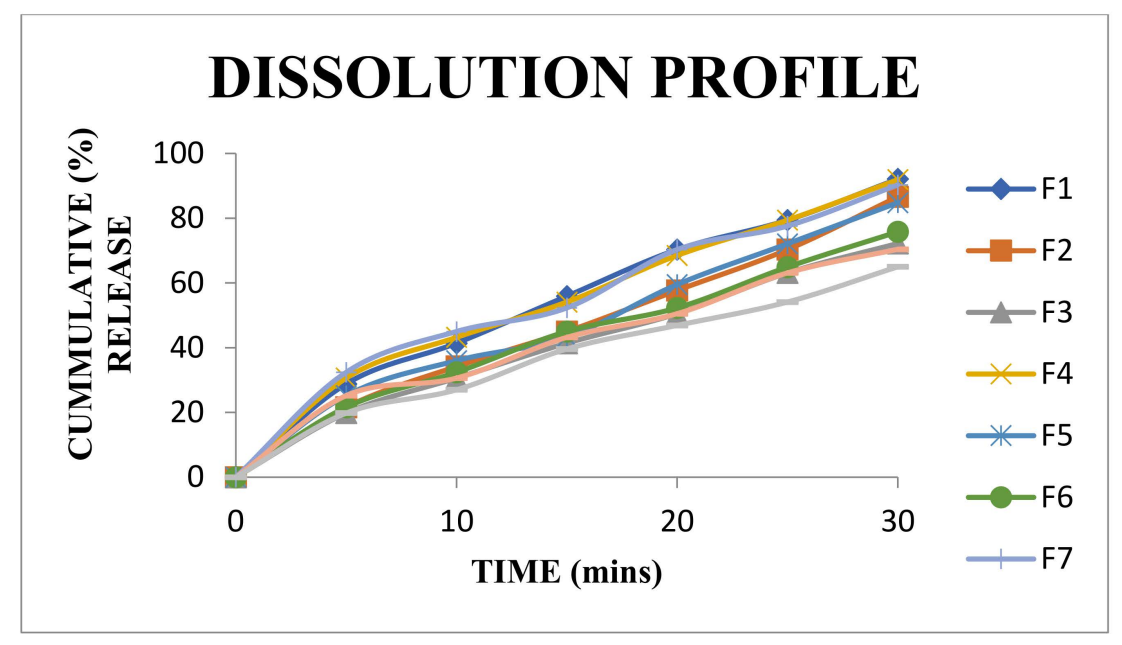

Figure 10. Comparative dissolution profiles for formulations F1 to F9. 


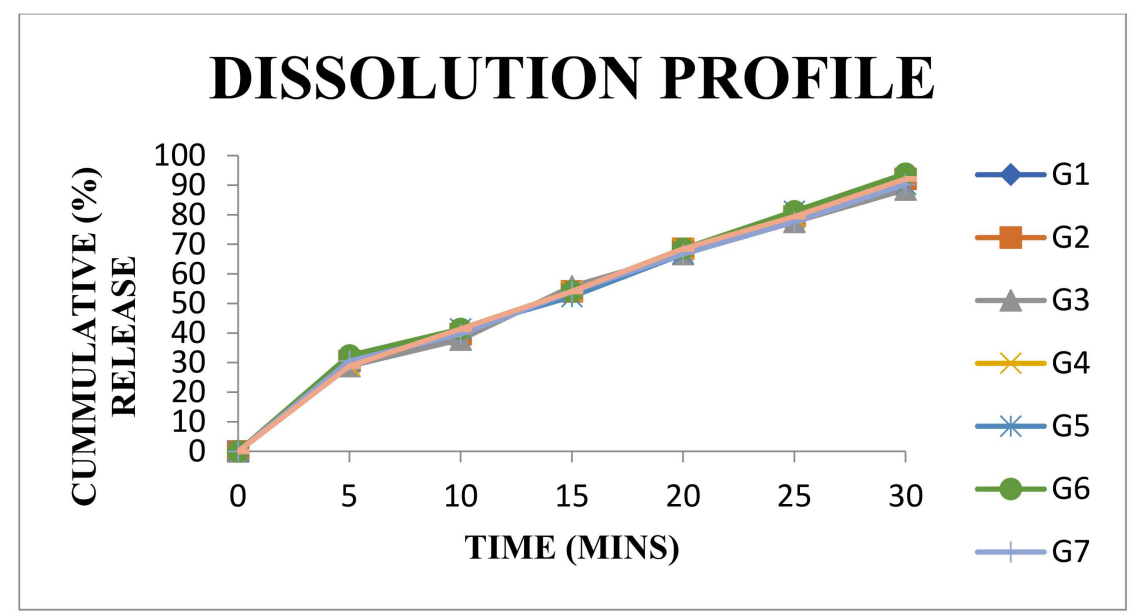

Figure 11. Comparative dissolution profiles for formulations G1 to G8.

\subsection{Statistical Analysis}

Statistical analysis of in vitro dissolution of the mucilage (CGM) with starch and PVP (standard binding agents) was performed using the DD SOLVER software for difference factor (f1), similarity factor (f2), and Rescigno index ( $\xi$ ) values. The results showed that the comparison of mean (R) reference and mean (T) test values of difference factor (f1) was below 15, similarity factor (f2) was above 50 and the Rescigno index was almost 0 (Table 11). These values displayed the binding properties of the isolated mucilage are similar to that of starch and PVP.

Statistical analysis of in vitro dissolution profile comparison of the mucilage (CGM) with MCCP, CCS, and SSG (standard disintegrating agents) was conducted using DD SOLVER software for difference factor (f1), similarity factor (f2), and Rescigno index ( $\xi$ ) values. The results demonstrated that the comparison of mean $(R)$ reference and mean (T) test values of difference factor (f1) was below 15, similarity factor (f2) was above 50, and the Rescigno index was almost 0 (Table 12). These values presented the disintegrating properties of isolated mucilage which are like that of standard disintegrating agents $(\mathrm{MCCP}$, CCS, and SSG).

\subsection{Accelerated Stability Study}

The stability studies at $25^{\circ} \mathrm{C} / 60 \% \mathrm{RH}, 30^{\circ} \mathrm{C} / 65 \% \mathrm{RH}$, and $40{ }^{\circ} \mathrm{C} / 75 \% \mathrm{RH}$, respectively were maintained for 1, 30, and 90 days as per ICH guidelines. The tablet formulation (F2) was carried out and the results are presented in Table 13. The hardness of tablets was increased slightly, but there were no significant changes in their physical appearance. The drug disintegration time and drug contents of the tablets were analyzed after 1, 30, and 90 days of the storage and there were no significant changes in the disintegration time, and drug content, correspondingly. This indicated that there were no significant changes in the physical as well as chemical characteristics of the formulations. Hence, it can be concluded that the developed formulation was stable and retained the crucial pharmaceutical properties over a period of three months. 
Table 13. Accelerated stability studies of F2.

\begin{tabular}{ccccccc}
\hline S. No & Temperature & $\begin{array}{c}\text { Time in } \\
\text { Days }\end{array}$ & $\begin{array}{c}\text { Physical } \\
\text { Change }\end{array}$ & $\begin{array}{c}\text { Hardness } \\
\mathbf{k g} / \mathbf{c m}^{2}\end{array}$ & $\begin{array}{c}\text { Disintegration } \\
\text { Time (min) }\end{array}$ & $\begin{array}{c}\text { Drug } \\
\text { Content (\%) }\end{array}$ \\
\hline & $25{ }^{\circ} \mathrm{C}$ & 1 & No change & 4.5 & $4 \mathrm{~min} / 22 \mathrm{~s}$ & 99.4 \\
1. & & 30 & No change & 5.0 & $5 \mathrm{~min} / 14 \mathrm{~s}$ & 98.9 \\
& & 90 & No change & 5.0 & $5 \mathrm{~min} / 27 \mathrm{~s}$ & 98.3 \\
\hline & $30{ }^{\circ} \mathrm{C}$ & 1 & No change & 4.5 & $4 \mathrm{~min} / 15 \mathrm{~s}$ & 99.6 \\
& & 30 & No change & 5.0 & $5 \mathrm{~min} / 32 \mathrm{~s}$ & 98.7 \\
& & 90 & No change & 5.5 & $6 \mathrm{~min} / 40 \mathrm{~s}$ & 98.1 \\
\hline 3. & $40{ }^{\circ} \mathrm{C}$ & 1 & No change & 4.5 & $4 \mathrm{~min} / 5 \mathrm{~s}$ & 98.9 \\
& & 30 & No change & 5.0 & $5 \mathrm{~min} / 34 \mathrm{~s}$ & 98.2 \\
& & 90 & No change & 5.0 & $5 \mathrm{~min} / 48 \mathrm{~s}$ & 97.8 \\
\hline
\end{tabular}

\section{Conclusions}

It can be concluded that the mucilage isolated from Coccinia grandis showed the presence of constituents such as carbohydrates, and polysaccharides. It has a near neutral $\mathrm{pH}$, which indicated that this mucilage does not irritate the GIT and is suitable for formulating an uncoated tablet. The compatibility studies through thermal methods of analysis and FTIR showed that there were no major interactions occurred between the mucilage and the model drug (paracetamol). The in vitro toxicity study revealed that this mucilage can be employed safely as a pharmaceutical excipient. The flow properties of granules prepared with mucilage had as good compressibility as that of the granules formulated using starch and PVP. Post-compression parameter analysis suggested that tablets formulated with mucilage had better hardness and friability than the tablets prepared with starch and PVP. As the binding concentration of mucilage is increased, the disintegration time also increased, like that of the tablets prepared with starch and PVP. The formulations exhibited a better and more consistent release as compared to the standard formulations using starch and PVP (standard binders). Considering all the above parameters, our study evidenced a good potential of the mucilage as a binder for tablet formulations. The disintegrant properties of the mucilage was studied in comparison with the standard super disintegrants (MCCP, CCS, and SSG.) The mucilage concentration at 3\% and below 3\% acted as a super disintegrating agent and exhibited faster tablet disintegration and drug dissolution, thereby helping for an effective therapy and improved patient compliance. Thus, the natural super disintegrant, the mucilage can be effectively used as a suitable disintegrant in formulating solid dosage form of tablets. Further, this work can be extended to in vivo toxicity assessment for its safety confirmation, besides predicting its sustaining action.

Supplementary Materials: The following supporting information can be downloaded at: https: / / www.mdpi.com/article/10.3390/polym14010215/s1, Figure S1: SEM analysis of mucilage in $\times 20,000$; Figure S2: SEM analysis of mucilage in $\times 55,000$; Figure S3: SEM analysis of mucilage in $\times 30,000$; Figure S4: Graph of concentration vs. \% cell viability; Figure S5: Image of cytotoxicity in $12.5 \mu \mathrm{g} / \mathrm{mL}$; Figure S6: Image of cytotoxicity in $25 \mu \mathrm{g} / \mathrm{mL}$; Figure S7: Image of cytotoxicity in $50 \mu \mathrm{g} / \mathrm{mL}$.; Figure S8: Image of cytotoxicity in $100 \mu \mathrm{g} / \mathrm{mL}$; Figure S9: Image of cytotoxicity in $200 \mu \mathrm{g} / \mathrm{mL}$; Figure S10: Image of cytotoxicity of control sample; Table S1: Standard graph of paracetamol drug; Table S2. Invitro drug release of tablets using isolated mucilage and standard binders; Table S3. In vitro drug release of tablets using isolated mucilage and standard disintegrants.

Author Contributions: K.B.I.: Conceptualization, data curation, writing original draft, formal analysis; S.G.: design of figures and tables, methodology, review \& editing; K.I.S.: writing-review \& editing; K.C.: project administration, Writing—review \& editing; M.F.B.: Writing—review \& editing; M.R.: review \& editing; C.B.: review \& editing. All authors have read and agreed to the published version of the manuscript.

Funding: This research received no external funding.

Institutional Review Board Statement: Not applicable.

Informed Consent Statement: Not applicable. 
Data Availability Statement: Not applicable.

Acknowledgments: Authors wish to thank the Management of Shree Venkateshwara College of Paramedical Sciences, Tamilnadu, India for the necessary facilities for this project. One of the authors (K.C.) would like to thank the Deanship of Scientific Research (RGP: 1/275/42), King Khalid University, Abha, Saudi Arabia. Author Chandrasekaran Balakumar gratefully acknowledges the Management of ITM University-Gwalior, India for resources.

Conflicts of Interest: The authors state that there are no known conflict of interest associated with this publication and there has been no significant financial support for this work that could have influenced its outcome.

\section{References}

1. Homayun, B.; Lin, X.; Choi, H.-J. Challenges and Recent Progress in Oral Drug Delivery Systems for Biopharmaceuticals. Pharmaceutics 2019, 11, 129. [CrossRef]

2. Tiwari, G.; Tiwari, R.; Sriwastawa, B.; Bhati, L.; Pandey, S.; Pandey, P.; Bannerjee, S.K. Drug Delivery Systems: An Updated Review. Int. J. Pharm. Investig. 2012, 2, 2-11. [CrossRef]

3. Choudhary, P.D.; Pawar, H.A. Recently Investigated Natural Gums and Mucilages as Pharmaceutical Excipients: An Overview. J. Pharm. 2014, 2014, 204849. [CrossRef] [PubMed]

4. Al-Khattawi, A.; Mohammed, A.R. Challenges and Emerging Solutions in the Development of Compressed Orally Disintegrating Tablets. Expert Opin. Drug Discov. 2014, 9, 1109-1120. [CrossRef] [PubMed]

5. Shanmugam, S. Granulation Techniques and Technologies: Recent Progresses. Bioimpacts 2015, 5, 55-63. [CrossRef] [PubMed]

6. Pal, R.S.; Pal, Y.; Wal, A.; Wal, P. Current Review on Plant Based Pharmaceutical Excipients. Open Med. J. 2019, 6, 1-5. [CrossRef]

7. Markl, D.; Zeitler, J.A. A Review of Disintegration Mechanisms and Measurement Techniques. Pharm. Res. 2017, 34, 890-917. [CrossRef] [PubMed]

8. Kuriyan, R.; Rajendran, R.; Bantwal, G.; Kurpad, A.V. Effect of Supplementation of Coccinia cordifolia Extract on Newly Detected Diabetic Patients. Diabetes Care 2008, 31, 216-220. [CrossRef] [PubMed]

9. Pekamwar, S.S.; Kalyankar, T.M.; Kokate, S.S. Pharmacological Activities of Coccinia Grandis: Review. J. Appl. Pharm. Sci. 2013, 3, 114-119. [CrossRef]

10. Sakharkar, P.; Chauhan, B. Antibacterial, Antioxidant and Cell Proliferative Properties of Coccinia Grandis Fruits. Avicenna J. Phytomed. 2017, 7, 295-307. [PubMed]

11. Purwar, S.; Bisht, V.; Banda, N.; Neetu, S.; Purwar, V.; Bisht, N.; Kr, B. Nutritional and Therapeutic Values of Coccinea Grandis: A Review. Int. J. Chem. Stud. 2020, 8, 1555-1561. [CrossRef]

12. Tamilselvan, N.; Thirumalai, T.; Elumalai, E.K.; Balaji, R.; David, E. Pharmacognosy of Coccinia Grandis: A Review. Asian Pac. J. Trop. Biomed. 2011, 1 (Suppl. 2), S299-S302. [CrossRef]

13. Taur, D.J.; Patil, R.Y. Mast Cell Stabilizing, Antianaphylactic and Antihistaminic Activity of Coccinia Grandis Fruits in Asthma. Chin. J. Nat. Med. 2011, 9, 359-362. [CrossRef]

14. Munasinghe, M.A.A.K.; Abeysena, C.; Yaddehige, I.S.; Vidanapathirana, T.; Piyumal, K.P.B. Blood Sugar Lowering Effect of Coccinia grandis (L.) J. Voigt: Path for a New Drug for Diabetes Mellitus. Exp. Diabetes Res. 2011, 2011, 978762. [CrossRef] [PubMed]

15. McCrae, J.C.; Morrison, E.E.; MacIntyre, I.M.; Dear, J.W.; Webb, D.J. Long-Term Adverse Effects of Paracetamol—A Review. Br. J. Clin. Pharmacol. 2018, 84, 2218-2230. [CrossRef] [PubMed]

16. Prajapati, V.D.; Jani, G.K.; Moradiya, N.G.; Randeria, N.P. Pharmaceutical Applications of Various Natural Gums, Mucilages and Their Modified Forms. Carbohydr. Polym. 2013, 92, 1685-1699. [CrossRef] [PubMed]

17. Hamman, H.; Steenekamp, J.; Hamman, J. Use of Natural Gums and Mucilages as Pharmaceutical Excipients. Curr. Pharm. Des. 2015, 21, 4775-4797. [CrossRef] [PubMed]

18. Wadhwa, J.; Nair, A.; Kumria, R. Potential of Plant Mucilages in Pharmaceuticals and Therapy. Curr. Drug Deliv. 2013, 10, 198-207. [CrossRef] [PubMed]

19. Killedar, S.G.; Nale, A.B.; More, H.N.; Nadaf, S.J.; Pawar, A.A.; Tamboli, U.S. Isolation, Characterization, and Evaluation of Cassia Fistula Linn. Seed and Pulp Polymer for Pharmaceutical Application. Int. J. Pharm. Investig. 2014, 4, 215-225. [CrossRef] [PubMed]

20. Bharath, S.; Reddy, P.; Deveswaran, R.; Basavaraj, B.V.; Madhavan, V. Extraction of Polysaccharide Polymer from Dioscorea Trifida and Evaluation as a Tablet Binder. Int. J. Pharm. Pharm. Sci. 2012, 4, 347-352.

21. Government of India, Ministry of Health \& Family Welfare. Pharmacopoeia of India: The Indian Pharmacopoeia, 1st ed.; Manager of Publications: Delhi, India, 2007. 